\title{
PENGGUNAAN GENERALIZED LINEAR AUTOREGRESSIVE MOVING AVERAGE (GLARMA) DALAM ANALISIS FENOMENA RESESI DI INDONESIA TAHUN 2008Q1 - $2020 Q 1$
}

(The Use of Generalized Linear Autoregressive Moving Average (GLARMA) in Analysis of Recession Phenomena in Indonesia $2008 Q 1$ - 2020Q1)

\author{
Dimas Maladzi Wibawa ${ }^{1}$, Nucke Widowati Kusumo Projo² \\ Politeknik Statistika STIS ${ }^{1}$ \\ Politeknik Statistika STIS ${ }^{2}$ \\ Jalan Otto Iskandardinata No.64C, Jakarta Timur, Daerah Khusus Ibukota Jakarta \\ E-mail: 16.9081@stis.ac.id
}

\begin{abstract}
ABSTRAK
Resesi merupakan penurunan secara signifikan dalam kegiatan ekonomi yang tersebar di seluruh aspek ekonomi. Resesi yang berkepanjangan dapat membawa perekonomian ke arah depresi. Indonesia termasuk ke dalam kategori fragile country yang menyebabkan kerentanan untuk masuk ke masa resesi semakin besar. Resesi merupakan bagian dari siklus bisnis yang mungkin akan dialami pada suatu waktu. Penelitian ini menggunakan model Generalized Linear Autoregressive Moving Average (GLARMA) untuk mengakomodir prediksi peluang dari fase resesi yang di definisikan dengan metode Bry Boschan dan meramal variabel independen dengan Autoregressive Integrated Moving Average (ARIMA). Variabel yang digunakan yaitu laju inflasi, fed fund rate, transaksi berjalan, harga minyak dunia, dan selisih U.S. 10Year-Bond dengan 3-Month LIBOR. Dari hasil penandaan siklus bisnis pada Produk Domestik Bruto riil, Indonesia mengalami delapan kali resesi sejak tahun 1993Q1-2020Q1 dengan durasi terpendek selama dua triwulan dan terpanjang selama delapan triwulan. Hasil dari model GLARMA(1,0) menunjukkan bahwa resesi di Indonesia didominasi oleh faktor eksternal yang dalam penelitian ini adalah selisih U.S. 10Year-Bond dengan 3-Month LIBOR dan fed fund rate memiliki pengaruh negatif secara signifikan terhadap resesi. Autoregressive lag-1 memiliki pengaruh positif terhadap resesi atau dengan kata lain kondisi yang terjadi pada triwulan sebelumnya berpengaruh terhadap terjadinya resesi di triwulan selanjutnya. Resesi di Indonesia diprediksi terjadi pada $2020 Q 3$.
\end{abstract}

Kata kunci: Resesi, GLARMA, Indonesia

\section{ABSTRACT}

Recession is a significant decline in economic activity that is spread across all aspects of the economy. $A$ prolonged recession can bring the economy into depression. Indonesia, which falls into the category of fragile country, makes the vulnerability of entry into recession even greater. Recession is part of a business cycle that might be experienced at some time. This study uses the GLARMA model to accommodate the prediction of opportunities from the recession phase that is defined by the Bry Boschan method and predict independent variables with ARIMA. The variables used are inflation rate, fed fund rate, current account, world oil price, and U.S. difference. 10 Year-Bond with 3-Month LIBOR. From the results of business cycle dating on real Gross Domestic Product, Indonesia has experienced eight recessions since 1993Q1-2020Q1 with the shortest duration of two quarters and the longest of eight quarters. The results from the GLARMA model (1.0) show that external factors, in this case are U.S. spreads. 10 Year-Bonds with 3-Month LIBOR and fed fund rates have a significant negative effect on the recession. The autoregressive lag-1 has a positive effect on recession or, in other words, the conditions that occurred in the previous quarter affected the recession in the next quarter. Moreover, it is predicted that a recession will occur in 2020Q3.

Keywords: Recession, GLARMA, Indonesia 


\section{PENDAHULUAN}

Secara sederhana resesi merupakan kelesuan perekonomian suatu negara yang ditandai dari banyak faktor ekonomi makro. Produk domestik bruto (PDB) menjadi indikator utama yang mencerminkan aktivitas ekonomi suatu negara dapat digunakan dalam salah satu indikator untuk menentukan terjadinya resesi. Fenomena resesi merupakan hal yang banyak dibicarakan oleh banyak negara, baik negara berkembang maupun negara maju. Resesi dapat berdampak pada ketidakstabilan ekonomi secara simultan yang mempengaruhi segala sektor.

Fenomena resesi pernah beberapa kali dialami oleh Indonesia terutama resesi dengan dampak cukup parah pada tahun 1998 yang diawali krisis moneter. Menurut Soedrajad Djiwandono (2016), krisis yang terjadi pada tahun 1998 disebabkan oleh faktor eksternal dengan adanya perubahan yang cepat dari sentimen pasar uang sehingga menimbulkan kepanikan dan kemudian terjadi efek yang menjalar mulai dari perbankan hingga sosial politik. Dengan adanya efek penularan tersebut yang tidak diimbangi indikator-indikator ekonomi yang kuat maka terjadi krisis yang akhirnya membuat pertumbuhan ekonomi Indonesia terkontraksi hingga minus 13,1\% di tahun 1998. Selain perekonomian Indonesia yang harus diperkuat, faktor eksternal juga harus diwaspadai dengan kondisi Indonesia yang melakukan banyak hubungan kerjasama baik dalam sektor finansial maupun non finansial dengan negara lain. Ketika terjadi gejolak pada suatu negara yang memiliki hubungan kerjasama dengan Indonesia terdapat kemungkinan jika Indonesia juga akan mengalami dampaknya.

Dampak dari resesi berkepanjangan bisa menyebabkan depresi yaitu fenomena depresi seperti yang dialami oleh Indonesia mulai dari pertengahan tahun 1997 hingga tahun 1998. Terjadinya depresi tidak hanya berdampak pada perekonomian saja namun bisa menjalar ke aspek lain seperti social politik. Sebagian besar sektor riil mengalami kontraksi yang cukup dalam sehingga pengan penanggulangan semakin kompleks dan disisi lain juga menjaga stabilitas politik. Akibat dari resesi yang berkepanjangan juga mengakibatkan peningkatan kemiskinan serta banyaknya pemutusan hubungan kerja. Walaupun masih ada beberapa sektor seperti pertanian yang dapat bertahan dibandingkan sektor lain.

Pada tahun 2013 Morgan Stanley memperkenalkan istilah fragile five country yang ditujukan pada lima negara yang dinilai sangat bergantung pada investasi modal asing namun masih sulit untuk melakukan peningkatan dalam pertumbuhan ekonominya. Masuknya Indonesia kedalam kategori fragile country menjadikan peringatan bahwa Indonesia masih rentan dengan adanya gejolak ekonomi yang terjadi di luar negeri. Peluang terjadinya resesi dari negara-negara fragile ini bisa semakin meningkat dengan melihat indikator yang membentuknya. Terdapat enam indikator yang digunakan Morgan Stanley dalam memasukan negara tersebut kedalam fragile five country, yaitu kondisi neraca berjalan, rasio cadangan devisa terhadap utang luar negeri, kepemilikan asing terhadap obligasi pemerintah, utang dalam Dolar AS, inflasi dan selisih suku bunga riil.

Indonesia mengalami penurunan tingkat pertumbuhan ekonomi cukup dalam pada kuartal kedua tahun 2009 hingga 4,14\%. Hal ini disebabkan dari terjadinya krisis di Amerika Serikat pada tahun 2008 yang ditandai dengan pertumbuhan ekonomi Amerika Serikat menyentuh nilai negatif. Pada tahun tersebut terjadi global recession yang dipicu oleh penyebab yang sama yaitu krisis di Amerika Serikat.

Belum banyak penelitian yang dilakukan dalam menganalisis peluang terjadinya resesi di Indonesia. Namun penelitian yang relevan dilakukan oleh Fornari dan Lemke (2010) di dalam macroprudential research European Central Bank meneliti prediksi peluang resesi pada tiga negara yaitu Amerika Serikat, Jerman, dan Jepang dengan memfokuskan pada variabel-variabel finansial. Prediksi didasarkan pada pendekatan probit yang banyak digunakan tetapi dinamika regressor dilihat dengan VAR. Penelitian menghasilkan bahwa yield curve signifikan sebagai predictor namun ramalan dapat ditingkatkan dengan menambah variabel-variabel finansial lain seperti short-term interest rate, stock return atau surat utang. Marc Labonte (2019) melakukan analisis penyebab dari terjadinya resesi khususnya di Amerika Serikat. Variabel-variabel yang dapat menjadi penyebab resesi diantaranya inflasi yang tinggi, financial bubble, stock market, dan guncanagan eksternal pada ekonomi seperti lonjakan harga minyak.

Kondisi perekonomian setiap negara berbeda sehingga dalam mendeteksi kemungkinan terjadinya resesi di Indonesia akan digunakan indikator yang berbeda dengan negara lain. Maka 530 
diperlukan variabel yang tepat dalam menyebabkan kemungkinan terjadinya resesi di Indonesia untuk mengantisipasi dan sebagai pertimbangan dalam membuat kebijakan. Penelitian ini bertujuan untuk menganalisis probabilita resesi di Indonesia menggunakan konsep dasar resesi pada siklus bisnis dan menerapkan metode logit time series atau Generalized Linear Autoregressive Moving Average (GLARMA) dalam pembentukan model. Secara spesifik penelitian ini menganalisis peluang terjadinya resesi di Indonesia dan menganalisis variabel-variabel ekonomi makro yang mempengaruhi terjadinya resesi di Indonesia yaitu: inflasi, Fed fund rate (ffr), Neraca Transaksi Berjalan, harga minyak, dan Selisih U.S. 10 Years - Bond dan 3-Month LIBOR (spread).

\section{METODE}

\section{Metode Pengumpulan Data}

Penelitian ini menggunakan data sekunder dengan cakupan observasi yang dilakukan pada penelitian ini adalah data Indonesia pada periode tahun 1993 triwulan I sampai tahun 2020 triwulan I. Data yang digunakan diantaranya Produk Dometik Bruto atas dasar harga berlaku 2010, laju inflasi bulanan, harga minyak WTI, neraca transaksi berjalan, fed fund rate,3-Month LIBOR, dan 12-Month LIBOR. Data tersebut diperoleh dari beberapa sumber yaitu Badan Pusat Statistik, Bank Indonesia, International Monetary Fund, Energy Information Administration, dan Global Rates.

\section{Metode Analisis}

\section{Analisis Deskriptif}

Dalam pembentukan variabel resesi, komponen yang digunakan adalah komponen siklus yang menunjukkan kondisi perekonomian suatu negara dengan variabel PDB riil apakah berada pada periode resesi atau tidak. Oleh karena itu, data perlu dihilangkan komponen musiman, tren dan ketidakteraturan untuk mendapatkan komponen siklus. Penghilangan komponen musiman dan ketidakteraturan menggunakan metode X12-ARIMA dan untuk penghilangan komponen tren menggunakan metode Hodrick-Prescott Filter (HP-Filter). Setelah didapatkan komponen siklus, variabel PDB diidentifikasi titik balik (turning point) dengan menggunakan metode Quarterly Bry Boschan (BBQ) yang merupakan pengembangan dari metode Bry Boschan routine (BB) pada penerapan data bulanan dengan memperhitungkan bahwa satu triwulan terdiri dari tiga bulan. Proses identifikasi resesi menggunakan metode BBQ dengan menggunakan software R 3.4.2.

Analisis deskriptif yang dilakukan akan melihat kondisi atau gambaran umum dari variabel variabel ekonomi ketika berada pada periode resesi. Analisis menggunakan grafik dengan diagram garis untuk variabel -variabel ekonomi dan clustered untuk resesi.

\section{Analisis Inferensia}

Analisis inferensia yang digunakan dalam penelitian ini adalah regresi logistik time series atau GLARMA. Adapun langkah-langkah pembentukan model GLARMA dalam penelitian ini adalah sebagai berikut:

1. Pembentukan model awal regresi logistik yang dirumuskan sebagai berikut:

$$
\operatorname{logit} \hat{\pi}(\mathrm{x})=\ln \left[\frac{\hat{\pi}\left(x_{t}\right)}{1-\hat{\pi}\left(x_{t}\right)}\right]=\hat{\beta}_{0}+\hat{\beta}_{1} I N F_{t}+\hat{\beta}_{2} F F R_{t}+\hat{\beta}_{3} T R A N_{t}+\hat{\beta}_{4} D M I N_{t}+\hat{\beta}_{4} S P R D_{t}
$$

dimana:

$$
\begin{aligned}
& \pi(\mathrm{x}) \quad=\text { Peluang terjadinya resesi } \\
& I N F_{t}=\text { Inflasi } \\
& F F R_{t}=\text { Fed fund rate } \\
& T_{R A N_{t}}=\text { Transaksi berjalan } \\
& D_{M I N_{t}}=\text { Perubahan harga minyak } \\
& \text { SPRD }_{t}=\text { Selisih U.S. } 10 \text { Years-Bond dan 3-Month LIBOR (Spread) }
\end{aligned}
$$


2. Diperoleh residual model regresi logistik pada tahap 1.

3. Identifikasi plot autocorrelation function (ACF) dan partial autocorrelation function (PACF) residual dari tahap 2 untuk mengetahui AR (p), MA (q) atau ARMA (p.q) yang akan digunakan untuk pertimbangan adanya korelasi dengan waktu dalam model GLARMA.

4. Pembentukan model GLARMA $(p, q)$ sebagai berikut :

$$
\ln \left[\frac{\hat{\pi}\left(x_{t}\right)}{1-\hat{\pi}\left(x_{t}\right)}\right]=\alpha+\hat{\beta}_{1} X_{1 t}+\hat{\beta}_{2} X_{2 t}+\hat{\beta}_{3} X_{3 t}+\hat{\beta}_{4} X_{4 t}+\hat{\beta}_{5} X_{5 t}+\sum_{j=1}^{p} \emptyset_{j} Z_{t-j}+\sum_{j=1}^{\bar{q}} \tilde{\theta}_{j} e_{t} j \hat{j}
$$

dimana

$Z_{t-j} \quad$ : residual dari regresi logistik periode ke-(t-i) (autoregressive)

$e_{t-j} \quad$ : residual dari GLARMA periode ke-(t-i) (moving average)

$\mathrm{p}$ : order dari variabel autoregressive

q : order dari variabel moving average

5. Melakukan pengujian parameter secara simultan menggunakan likelihood ratio test

6. Pengujian kesesuaian model GLARMA menggunakan uji Ljung-Box dan Hosmer Lemeshow

Setelah mendapatkan model terbaik yang dapat memprediksi resesi maka dilakukan peramalan untuk variabel-variabel independen dengan menggunakan autoarima yang terdapat pada $\mathrm{R}$ programming. Autoarima mencari model ARIMA terbaik dengan melihat AIC dari berbagai orde ARIMA yang terbentuk. Peramalan ARIMA dengan prosedur Box-Jenkins terdapat beberapa tahap mulai dari identifikasi model, estimasi parameter, cek diagnosa dan peramalan.

\section{HASIL DAN PEMBAHASAN}

\section{Kondisi Resesi di Indonesia sejak Kuartal-I 1993 - Kuartal-IV 2019}

Dalam kurun waktu tahun 1993 hingga awal tahun 2020 Indonesia mengalami delapan kali masa resesi dengan melihat siklus bisnis dari indikator utama perekonomian Indonesia yaitu PDB. Terdapat tujuh kali periode resesi dengan durasi yang berbeda di setiap periodenya. Periode resesi dengan durasi paling panjang terdapat pada tahun 2013 triwulan III hingga tahun 2015 triwulan III. Periode masing-masing resesi sejak tahun 1993 hingga 2020 triwulan I dapat dilihat pada gambar 1. Panjang durasi dari masing-masing periode resesi memiliki variasi dimana durasi terpendek selama dua triwulan pada periode 2003Q3-2003Q4 dan durasi terpanjang selama delapan triwulan sejak 2013Q3.

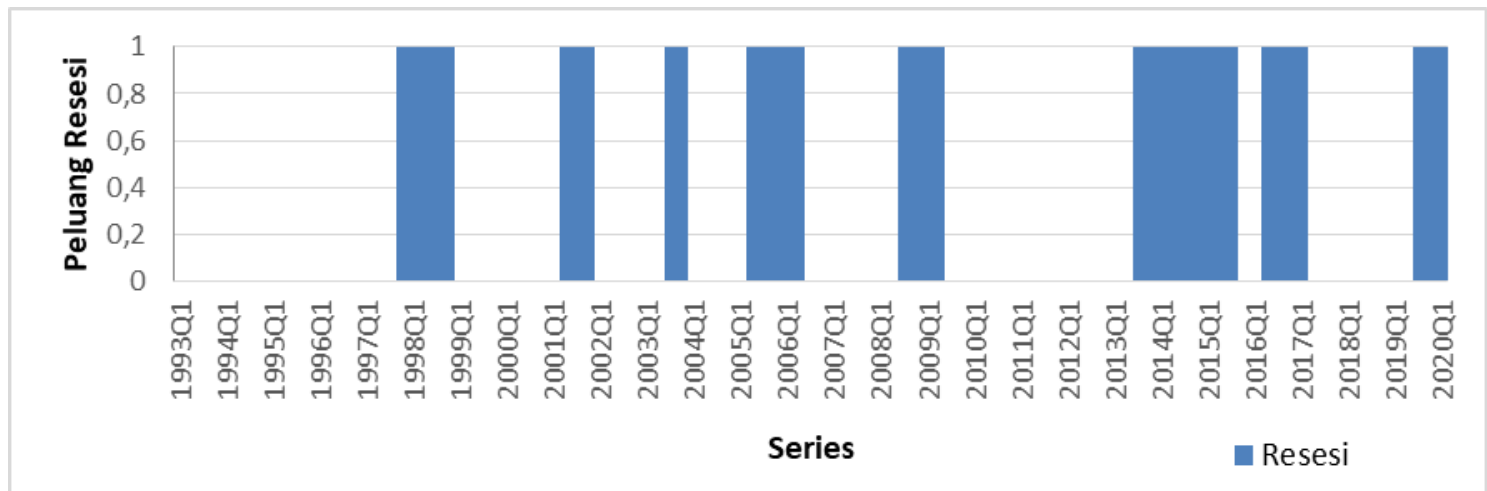

Gambar 1. Diagram Clustered Fase Resesi yang terjadi di Indonesia 1993Q1 - 2020 Q1.

Periode resesi yang dialami Indonesia baru dialami pertama kalinya pada tahun 1997 triwulan IV semenjak tahun 1993 dimana ekonomi terus tumbuh tinggi pada era pemerintahan orde baru. Namun tahun 1997 mulai terjadi krisis finansial yang ditimpa oleh negara-negara di kawasan Asia. Krisis moneter ini terjadi, meskipun fundamental ekonomi Indonesia di masa lalu dipandang cukup kuat. Fundamental ekonomi yang kuat yaitu pertumbuhan ekonomi yang cukup tinggi, laju inflasi terkendali, tingkat pengangguran relatif rendah, neraca pembayaran secara keseluruhan masih 
surplus meskipun defisit neraca berjalan cenderung membesar namun jumlahnya masih terkendali, cadangan devisa masih cukup besar, realisasi anggaran pemerintah masih menunjukkan sedikit surplus (Tarmidi, 1999). Krisis yang berkepanjangan ini adalah krisis merosotnya nilai tukar rupiah yang sangat tajam, akibat dari serbuan yang mendadak dan secara bertubi-tubi terhadap dollar AS (spekulasi) dan jatuh temponya utang swasta luar negeri dalam jumlah besar.

Pada gambar 1 terlihat bahwa pada tahun 2001 Indonesia kembali mengalami resesi yang cenderung terjadi akibat faktor internal. Pada tahun tersebut terjadi politik yang tidak stabil bahkan dipertengahan tahun terjadi peristiwa turunnya Abdurahman Wahid sebagai Presiden Republik Indonesia yang kemudia digantikan oleh wakilnya Megawati Soekarno Putri. Pada tahun 2001 pertumbuhan ekonomi Indonesia mengalami perlambatan hingga 3,6\% yang pada tahun sebelumnya sebesar $5 \%$.

Perekonomian Indonesia mengalami resesi yang cukup singkat pada periode tahun 2003 triwulan III dan triwulan IV jika dibandingkan dengan periode resesi lainnya. Pasca krisis moneter yang mengakibatkan resesi yang cukup dalam, Indonesia sudah beranjak membangun pondasi perekonomian yang cukup kuat. Tahun 2003 awal terjadi epidemik yang terjadi di negeri tirai bambu yaitu virus SARS. Dampak yang dialami China adalah melambatnya pertumbuhan ekonomi sebesar $1 \%$ pada triwulan II. Hal ini tentu tidak saja bagi negara China yang terdampak namun Indonesia yang merupakan mitra dagang tentunya mengalami penurunan di beberapa sektor riil. Perlambatan output industrial di China akan menurunkan permintaan terhadap bahan baku dan bahan pembantu dalam proses produksi. Sekitar 29 persen dari barang yang diekspor China, bahan mentah dan penolongnya berasal dari Indonesia terutama batu bara dan kelapa sawit.

Mulai 1 Maret tahun 2005 pemerintah resmi mengurangi subsidi terhadap BBM melalui Peraturan Presiden Nomor 22 tahun 2005 sehingga berbagai jenis BBM mengalami kenaikan harga sekitar 22\% sampai 39\%. Berdasarkan teori supply demand, ketika terjadi kenaikan biaya produksi maka kurva penawaran akan bergeser ke kiri sehingga pada keseimbangan baru terjadi penurunan output dan kenaikan harga. Penurunan output pada berbagai sektor terdampak dari kenaikan harga BBM dapat memperlambat laju pertumbuhan dan kenaikan harga komoditas berimplikasi pada peningkatan laju inflasi.

Pada tahun 2008 terjadi fenomena besar yang memiliki dampak hingga seluruh dunia. Bermula dari program subprime mortgage yang ada di Amerika Serikat mengalami kegagalan karena ketidamampuan debitor dalam membayar kredit. Hal ini tentu disebabkan dari program ini yang merupakan kredit perumahan yang diberikan kepada debitor yang tidak memiliki sejarah pengkreditan dan dinilai tidak mampu membayar kredit tersebut serta digolongkan sebagai kredit dengan resiko tinggi. Amerika adalah negara adi daya (super power) yang memiliki kekuatan ekonomi terkuat di dunia, dan memberikan kontribusi sekitar $20-30 \%$ dari perputaran ekonomi dunia (Sihono, 2008).

Gejolak perekonomian kembali terjadi pada tahun 2013 yang masih ada sedikit dampak dari resesi global pada tahun 2008 yang menuju masa recovery. Pertumbuhan Indonesia turun hingga dibawah $6 \%$ serta neraca perdagangan yang terperosok kedalam nilai defisit yang cukup dalam pada awal tahun yaitu sebesar USD 1,63 miliar dan mencapai USD 24,4 miliar atau sekitar 2,8 persen dari Produk Domestik Bruto (PDB). Ini juga merupakan defistit terbesar pertama sejak kejatuhan tahun 1997-1998 sampai tahun 2011 yang mengalami surplus. Tidak hanya itu, terjadi penurunan nilai tukar mata uang di sejumlah negara termasuk Indonesia. Selama Juni-Agustus 2013, nilai tukar Lira Turki jatuh sebesar 10 persen, nilai tukar Rupee India jatuh sebesar 20 persen, dan nilai tukar Rupiah serta Brazil jatuh sekitar 15 persen.

\section{Kondisi Inflasi Selama Periode Resesi}

Menurut konsep BPS inflasi merupakan kecenderungan naiknya harga barang dan jasa pada umumnya yang berlangsung secara terus menerus. Maka ketika terjadi inflasi yang sangat tinggi merupakan tanda bahwa harga berbagai komoditas sedang mengalami kenaikan yang cukup tajam sehingga membuat daya beli dari masyarakat dan pelaku ekonomi menjadi menurun. 


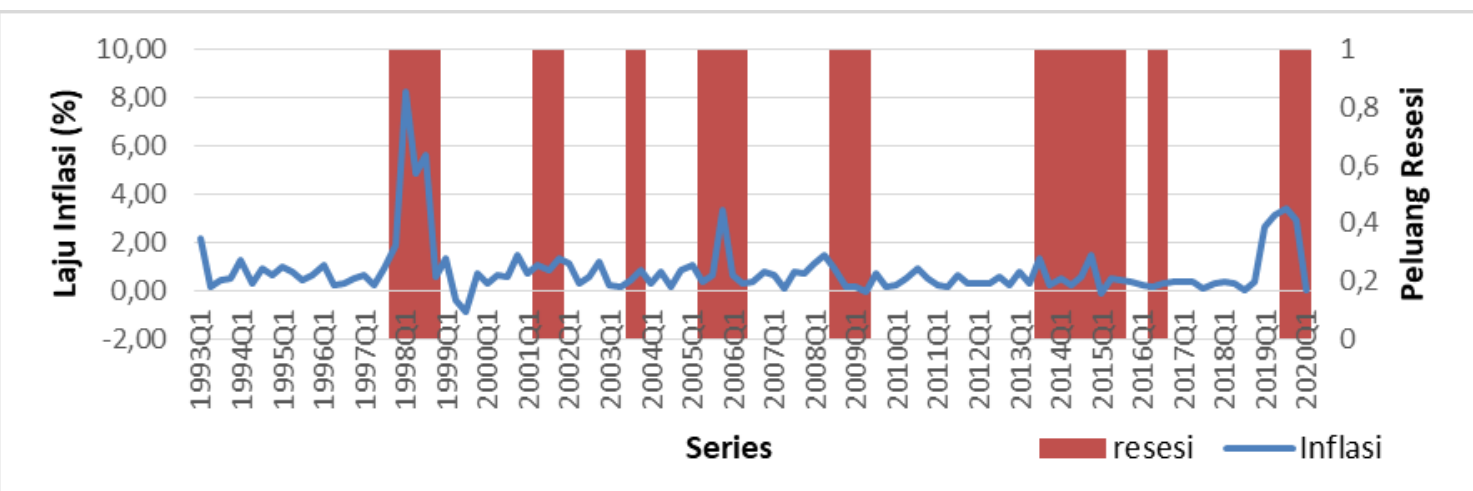

Gambar 2. Grafik laju inflasi Indonesia dan diagram clustered fase resesi yang terjadi di Indonesia 1993Q1 -2020 Q1.

Gambar 2 memperlihatkan bahwa rata-rata laju inflasi memiliki nilai yang tinggi pada periode resesi. Hal tersebut dapat terlihat jelas pada periode sesi di tahun 1998, 2005-2006, dan akhir tahun 2019. Walaupun terdapat laju inflasi yang bernilai rendah pada periode resesi seperti di tahun 2009 namun inflasi yang tinggi sudah terjadi pada satu triwulan sebelum terjadi resesi. Dapat dikatakan bahwa dampak dari tingginya inflasi pada beberapa kasus tidak secara langsung mempengaruhi terjadinya resesi namun kemungkinan terdapat lag waktu dari proses berjalannya perekonomian.

\section{Kondisi Fed fund rate (ffr) Selama Periode Resesi}

Fed fund rate menjadi faktor eksternal yang dapat berdampak bagi perekonomian negaranegara lain di luar Amerika Serikat termasuk Indonesia. Fed fund rate merupakan instrument bagi Amerika Serikat dalam mengontrol laju inflasi dan pendorong kegiatan ekonomi. Ketika terjadi resesi The Fed cenderung melakukan pemangkasan pada fed fund rate untuk meningkatkan pertumbuhan ekonomi. Karena pada saat ffr mengalami penurunan, pelaku ekonomi cenderung untuk tidak melakukan saving dan akan lebih memilih membelanjakan uangnya sehingga dapat meningkatkan pergerakan ekonomi menuju arah ekspansi.

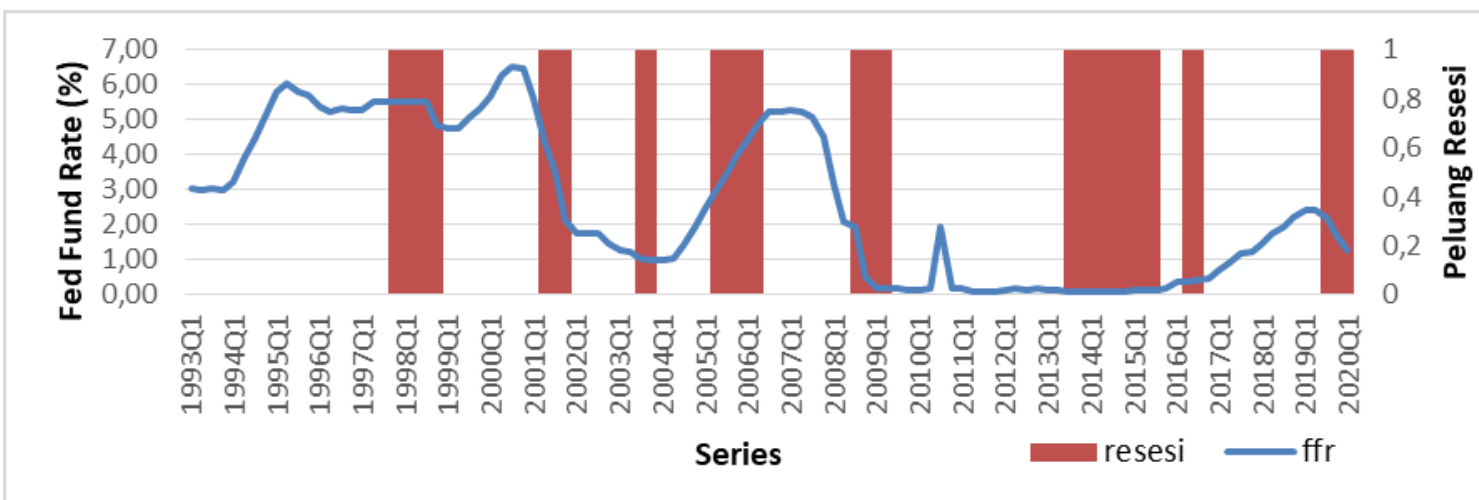

Gambar 3. Grafik fed fund rate dan diagram clustered fase resesi yang terjadi di Indonesia 1993Q1$2020 Q 1$.

Gambar 3 menampilkan pergerakan fed fund rate pada periode resesi yang terjadi di Indonesia. Pada resesi tahun 1997-1998, nilai fed fund rate berada pada posisi cukup tinggi yaitu berkisar di angka 5\%. Hal ini terjadi karena resesi yang terjadi pada periode tersebut disebabkan dari krisis moneter yang terjadi di kawasan Asia. Sehingga kebijakan The Fed untuk tidak menurunkan fed fund rate karena Amerika Serikat tidak terlalu terdampak. Namun setelah periode tersebut selama periode resesi, fed fund rate cenderung mengalami penurunan dana berada pada level rendah. Tetapi terdapat satu periode resesi dimana nilai fed fun rate justru mengalami peningkatan karena Amerika Serikat sedang berada dalam masa ekspansi sehingga tinggi nya nilai fed fund rate membuat banyak investor masuk ke pasar uang Amerika Serikat. 


\section{Kondisi Selisih U.S. 10 Years - Bond dan 3-Month LIBOR (spread) Selama Periode Resesi}

Suku bunga pada obligasi jangka panjang mencerminkan sebagian jalur suku bunga jangka pendek yang diharapkan selama rentang waktu obligasi. Arah yang diharapkan ini dipengaruhi oleh pandangan tentang siklus bisnis dan kebijakan moneter. Jika pelaku pasar mengharapkan penurunan, mereka kemungkinan juga mengantisipasi bahwa Federal Open Market Committee (FOMC) akan memangkas suku bunga kebijakan di masa depan untuk menyediakan akomodasi kebijakan moneter. Ekspektasi suku bunga yang lebih rendah di masa depan akan mengurangi suku bunga jangka panjang, dan ini dapat menghasilkan kurva hasil yang terbalik.

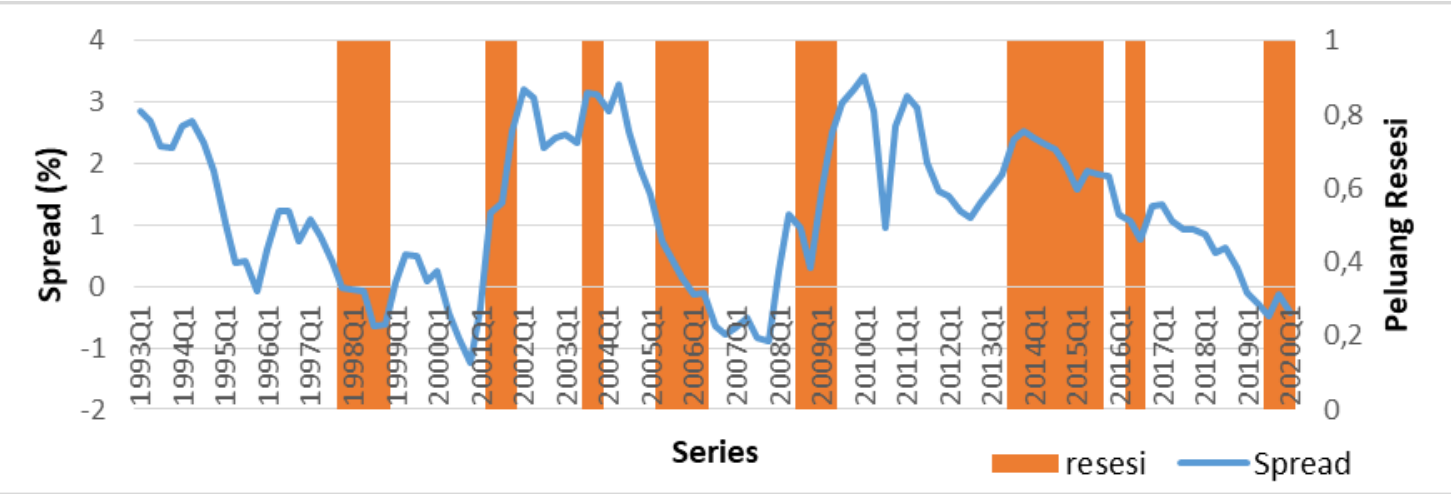

Gambar 4. Grafik selisih US 10Y-Bond dengan 3-Month LIBOR dan diagram clustered fase resesi yang terjadi di Indonesia 1993Q1 - 2020Q1

Gambar 4 menampilkan kondisi pergerakan selisih US 10Y-Bond dengan 3-Month LIBOR (spread) yang diawali posisi yang cukup tinggi pada awal tahun 1993. Ketika nilali selisih tinggi mengidikasikan bahwa suku bunga jang panjng masih dalam keadaan normal dan sentiment pasar juga percaya pada negara. Hingga penggunaan tren yang turun signifikan sampai di akhir tahun 1998. Walaupun sempat mengalami peningkatan spread, terdapat penurunan yang secara bertahap mengalami penurunan.

\section{Variabel - variabel yang Mempengaruhi Peluang Terjadinya Resesi}

\section{Stasioneritas Data}

Analisis yang dilakukan pada data dengan jenis time series didahulukan pada asumsi stasioneritas data. Karna data yang tidak bersifat stasioner dapat menimbulkan hasil regresi yang bersifat spurious. Uji stasioneritas data yang digunakan yaitu uji Augmented Dickey Fuller dapat disimpulkan bahwa terdapat empat variabel yang stasioner pada level dan satu variabel yang stasioner pada first difference dengan taraf signifikansi 5\%. Sehingga pembentukan model bisa dilakukan dengan hasil model yang tidak spurious.

\section{Pembentukan Model Regresi Logistik}

Faktor-faktor yang menyebabkan terjadinya resesi di Indonesia dapat diketahui melalui analisis inferensia dengan melihat signifikansi pengaruh variabel independen. Resesi yang merupakan nilai biner apakah terjadi resesi atau tidak dapat diterapkan analisis regresi logistik biner. Berikut hasil persamaan regresi logistik biner dari lima variabel independen:

$$
\begin{aligned}
& \ln \left[\frac{\hat{\pi}\left(x_{t}\right)}{1-\hat{\pi}\left(x_{t}\right)}\right]=-0,1717+0,7489^{*} I N F_{t}-0,4047^{*} F F R_{t}+0,000031 T_{R A N} \\
& -0,0461^{*}{ }^{2} I_{t}-0,3411 S P R D_{t}
\end{aligned}
$$


Hasil persamaan regresi logistik menunjukkan bahwa terdapat tiga variabel yang berpengaruh signifikan terhadap terjadinya resesi pada taraf signifikansi $10 \%$. Setelah terbentuk model regresi logistik maka dilakukan analisis pola residual dari model regresi logistik untuk mendapatkan orde pada pembentukan model GLARMA dengan menggunakan ACF dan PACF.

Dari proses dengan menggunakan $R$ programming dihasilkan plot AFC dan PACF seperti pada lampiran 1 dapat dilihat bahwa pola ACF menunjukkan pergerakan secara eksponensial dan lampiran 2 pola PACF sendiri memperlihatkan adanya cut off pada lag pertama. Sehingga dapat disimpulkan bahwa orde dari GLARMA yang terbentuk adalah GLARMA $(1,0)$.

\section{Pemilihan Model Terbaik}

Dalam pemilihan model terbaik antara regresi logistik dan GLARMA $(1,0)$ dengan melihat nilai AIC untuk merepresentasikan model yang paling sesuai. Selain itu juga dilihat dari uji LR dan Wald untuk melihat apakah model regresi logistik ataukah GLARMA yang lebih tepat digunakan. Pengujian kesesuaian model menunjukkan bahwa dari nilai AIC model GLARMA $(1,0)$ memiliki nilai yang lebih kecil (99.96) dibandingkan model regresi logistic (123.19). Hal ini mengindikasikan bahwa model GLARMA $(1,0)$ memiliki kemampuan lebih baik dalam menjelaskan observasi. Hasil dari uji Likelihood Ratio dalam pengujian Goodness of Fit menunjukkan hasil tolak $\mathrm{HO}$ pada taraf signifikansi $1 \%$ ( $p$-value=5.08e-07). Sehingga dapat disimpulkan bahwa model GLARMA $(1,0)$ merupakan model terbaik dalam menjelaskan terjadinya resesi di Indonesia. Berikut hasil persamaan GLARMA $(1,0)$ :

$$
\begin{aligned}
\ln \left[\frac{\hat{\pi}\left(x_{t}\right)}{1-\hat{\pi}\left(x_{t}\right)}\right]= & -0,8088+0,503 I N F_{t}-0,6632^{*} F F R_{t}+0,000056 \text { TRAN }_{t} \\
& -0,01772 \text { DMIN }_{t}-0,878^{*} S P R D_{t}+0,7605^{*} Z_{t-1}
\end{aligned}
$$

Setelah mendapatkan model terbaik kemudian dilakukan uji Ljung Box dalam melihat apakah residual dari model GLARMA $(1,0)$ memiliki sifat white noise. Hasil yang didapatkan bahwa pada tingkat signifikan 5\% uji Ljung-Box menunjukkan hasil gagal tolak HO. Dan untuk hasil uji Hosmer Lemeshow menunjukkan hail gagal tolak HO. sehingga dapat disimpulkan bahwa model GLARMA $(1,0)$ sudah tepat untuk digunakan dalam menjelaskan fenomena resesi di Indonesia. Pada Lampiran 3 menunjukkan bahwa kecenderungan peluang fitted value regresi logistik dan GLARMA $(1,0)$ dengan nilai observasi bahwa model GLARMA $(1,0)$ memiliki kecenderungan peluang lebih mendekati nilai observasi.

\section{Intepretasi Model Akhir}

Pada model akhir yang didapat yaitu $\operatorname{GLARMA}(1,0)$ memperlihatkan beberapa variabel yang memiliki pengaruh signifikan terhadap terjadinya resesi yaitu fed fund rate, dan selisih U.S. 10 Year-Bond dengan 3-Month LIBOR serta AR(1). Dan untuk variabel inflasi, neraca pembayaran transaksi berjalan atau current account dan perubahan harga minyak (first difference) tidak berpengaruh signifikan pada tingkat signifikansi $10 \%$. Model ini dapat memprediksi ketepatan terjadinya resesi sebesar $83,49 \%$.

Terdapat dua faktor eksternal yang memiliki pengaruh signifikan terhadap resesi, yaitu fed fund rate dan spread. Kedua variabel ini memiliki pengaruh negative terhadap terjadinya resesi di Indonesia. Hal ini sesuai pada penelitian terdahulu yang dilakukan Young dan Qian bahwa selisih LIBOR jangka panjang dengan jangka pendek memiliki kekuatan prediksi terhadap resesi yang terjadi di Amerika Serikat. Ketika nilai selisih LIBOR jika semakin kecil hingga mengindikasikan bahwa LIBOR jangka panjang memiliki nilai yang lebih kecil dibandingkan LIBOR jangka pendek. Berdasarkan persmaan GLARMA $(1,0)$ koefisien dari variabel spread yaitu $-0,878$ atau dengan kata lain setiap kenaikan selisih U.S. 10Year-Bond dengan 3-Month LIBOR akan meningkatkan kecenderungan Indonesia untuk tidak terjadi resesi sebesar 2,406. Fenomena ini menunjukkan bahwa pelaku pasar uang kurang memiliki kepercayaan terhadap kondisi perekonomian jangka panjang pada perekonomian dunia. Maka hal ini memicu terjadinya resesi pada negara-negara 
seperti Amerika Serikat, Uni Eropa bahkan negara Asia dan juga Indonesia. Melihat terjadinya resesi global tentu dampaknya akan terasa bagi banyak negara khususnya Indonesia.

Fed fund rate yang merupakan faktor eksternal juga memiliki pengaruh yang signifikan terhadap terjadinya resesi di Indonesia. Variabel ini memiliki koefisien sebesar -0,6632 atau dengan kata lain ketika terjadi kenaikan fed fund rate sebesar $1 \%$ maka akan meningkatkan kecenderungan Indonesia untuk tidak terjadi resesi sebesar 1,94. The FED menurunkan fed fund rate ketika terjadi resesi dalam rangka menjaga laju inflasi dan menjadikan perekonomian dalam kondisi ekspansi untuk menstimulus pelaku ekonomi. Maka ini merupakan tanda bagi Indonesia ketika nilai fed fund rate mengalami penurunan bahkan cukup tajam adalah indikasi negara Amerika Serikat sedang dalam masa resesi.

Variabel autoregressive (Zt-1) menghasilkan koefisien dengan pengaruh positif yang signifikan terhadap terjadinya resesi di Indonesia pada tingkat signifikansi $1 \%$. Dengan koefisien 0,7605 atau dalam kata lain kondisi variabel diluar model regresi logistik pada triwulan sebelumnya maka kecenderungan untuk terjadi resesi pada triwulan selanjutnya sebesar 2,139. Beberapa indikator makroekonomi tentu akan terjadi ketidakstabilan baik dalam sektor riil ataupun moneter sehingga pemulihan tidak dapat langsung dilakukan pada masa itu juga dan menjadikan triwulan selanjutnya masih terdampak pada masa resesi sebelumnya. Dalam hal ini menunjukkan bahwa semakin tingginya kondisi eksternal triwulan sebelumnya yang tidak tercakup dalam model sangat mempengaruhi kemungkinan terjadinya resesi di Indonesia.

Koefisien dari inflasi menunjukkan arah yang positif namun tidak berpengaruh secara signifikan pada terjadinya resesi. Jika dilihat pada pembentukan model regresi logistik dimana belum adanya pengaruh dari autoregressive makan variabel inflasi memiliki pengaruh yang signifikan. Namun dengan pembentukan model GLARMA yang megikutsertakan variabel autoregressive memiliki pengaruh lebih dominan dibandingkan variabel inflasi. Walaupun tidak signifikan, inflasi menunjukkan bahwa terjadinya resesi dipengaruhi secara positif. Dan sesuai pada penelitian Marc Labonte yang menyatakan bahwa resesi bisa disebabkan pada tingkat inflasi yang tinggi maka ketika laju inflasi semakin tinggi akan semakin memungkinkan terjadinya resesi. Dan dapat dilihat pada grafik (anades inflasi) rata-rata laju inflasi memiliki kecenderungan nilai yang tinggi pada setiap periode terjadinya resesi. Hal ini memungkinkan bahwa adanya pengaruh dari inflasi secara positif terhadap resesi.

Variabel perubahan harga minyak dunia tidak memiliki pengaruh yang signifikan terhadap terjadinya resesi di Indonesia. Indikasi awal dapat terlihat pada analisis deskriptif dimana ketika masuk fase resesi harga minyak berada pada level yang tinggi namun saat masih dalam periode resesi yang sama terjadi fenomena harga minyak jatuh cukup dalam.

Neraca transaksi berjalan tidak memiliki pengaruh yang signifikan terhadap terjadinya resesi di Indonesia yang indikasi ini dapat terlihat dari analisis deskriptif. Pada resesi tahun 1998 yang pada dasarnya terjadi krisis di kawasan Asia justru neraca transaksi berjalan mengalami surplus bahkan untuk nilai yang cukup tinggi. Dalam hal ini terjadi penurunan nilai mata uang rupiah terhadap dollar yang dapat menguntungkan pelaku eksportir dan disisi lain karna adanya resesi penurunan permintaan konsumsi di Indonesia menurun. Dan neraca transaksi berjalan baru mengalami defisit pada awal tahun 2012 dimana baru terjadi resesi beberapa triwulan setelahnya. Walaupun neraca transaksi berjalan sebagai salah satu indikator fragile country tetapi tidak memilki pengaruh signifikan pada terjadinya resesi di Indonesia.

Dari hasil prediksi dengan model GLARMA $(1,0)$ yang meramal nilai dari setiap variabel independen dengan auto.arima didapatkan peluang pada tahun 2020 triwulan kedua sebesar 0,8247786 dan pada triwulan ketiga sebesar 0,6869844 . Nilai peluang yang cukup besar dengan adanya indikasi terjadinya resesi dengan melihat kondisi pada tahun 2020 dimana terjadinya pandemik virus covid-19 yang terjadi di seluruh dunia. Dengan adanya kebijakan physical distancing dan Pembatasan Sosial Berskala Besar (PSBB) membuat kegiatan ekonomi menjadi terganggu baik dalam ruang lingkup usaha menengah mikro kecil hingga industri besar. Dengan adanya pelonggaran kebijakan PSBB di beberapa daerah memungkinkan kegiatan ekonomi kembali bergerak di dalam ruang lingkup tatanan kenormalan baru. Maka peluang pada triwulan ketiga tahun 2020 sudah menurun sesuai dengan harapan kebijakan pemerintah dalam menjaga stabilitas ekonomi di tengah pandemi. 


\section{KESIMPULAN}

Berdasarkan penelitian yang telah dilakukan dapat ditarik beberapa kesimpulan Pergerakan setiap indikator makro ekonomi dalam dan luar negeri tidak menunjukkan pola yang konsisten ketika berada dalam masa resesi diakibatkan adanya faktor-faktor guncangan yang seringkali tidak terduga sehingga menyebabkan resesi walaupun masih terdapat indikasi kecenderungan arah pergerakan dari masing-masing indikator selama masa resesi.

Kondisi perekonomian dan indikator eksternal yang tidak terduga pada triwulan sebelumnya sangat mempengaruhi terjadinya resesi di triwulan selanjutnya. Faktor-faktor dari luar Indonesia (fed fund rate, spread 3 Month LIBOR dan 10 Years Bond) memiliki pengaruh yang lebih kuat dibandingkan dengan faktor-faktor internal (inflasi, transaksi berjalan).

Model GLARMA $(1,0)$ dapat memprediksi peluang terjadinya resesi dengan baik melalu hasil klasifikasi keberhasilan prediksi. Sehingga dapat menentukan peluang resesi pada masa yang akan datang dengan mengetahui variabel yang mempengaruhi. Dan terdapat potensi terjadi resesi dari model prediksi yang dihasilkan dengan adanya fakta pendukung.

\section{UCAPAN TERIMA KASIH}

Terima kasih sebesar-besarnya kepada Politeknik Statistik STIS untuk seluruh dukungan yang diberikan sehingga peneliti dapat melaksanakan penelitian ini. Terima kasih juga kepada penyedia data di penelitian ini: Badan Pusat Statistik, Bank Indonesia, International Monetary Fund, Energy Information Administration, dan Global Rates, dukungan data yang diberikan sangat berarti bagi penelitian ini.

\section{DAFTAR PUSTAKA}

Business Cycle Dating Committee. (2003). The NBER's Recession Dating Procedure". National Bureau of Economic Research.

Benjamin, M.A et. all. (2003). Generalized Autoregressive Moving Avarage Models. Journal of the American Statistical Association, 98:41

Djiwandono, Soedrajad. (2016). Indonesia Menghadapi Perkembangan Ekonomi Dunia yang Sarat Risiko dan Ketidakpastian. Bank Indonesia Institute.

Fornari, F. \& Lemke, W. (2010). Predicting Recession Probabilities with Financial Variables Over Multiple Horizons. Macroprudential Research Network, 1225

Harding, D. \& Pagan, A. (2012). Can We Predict Recession?. Euroindicators Working Papers,024:1977-3331

Imansyah, M. H. (2009). Krisis Keuangan di Indonesia Dapatkah Diramalkan. Jakarta: Elex Media Komputindo

Kauppi, H. and Saikkonen, P. (2008). Predicting U.S. Recessions with Dynamic Binary

Response Models. Review of Economics and Statistics, 90:777-91.

Labonte, Marc. (2019). What Causes a Recession?. The National Bureau of Economic Research.

Lee, Y. S \& Zhu, Q. (2009). Prediction of Recession [Tesis]. Burnaby : Simon Fraser University

$\mathrm{Ng}$, Serena. \& Wright, J.H. (2013). Facts And Challenges From The Great Recession For Forecasting

And Macroeconomic Modeling. NBER Working Paper Series, 19469

Nyberg, H. (2010). Dynamic Probit Models and Financial Variables in Recession Forecasting.

Journal of Forecasting, 29:215-30.

Pettinger, Tejvan. (2020). "Inflation and Recession". Economics Help. Diakses pada 4 Maret 2020 melalui https://www.economicshelp.org/blog/2314/inflation/inflation-and-the-recession/

Rudebusch, G.D. \& Williams, J.C. (2008). Forecasting Recessions:The Puzzle of the Enduring Power of the Yield Curve. Federal Reserve Bank Of San Francisco Working Paper Series,16

Sihono, Teguh. "Krisis Finansial Amerika Serikat dan Perekonomian Indonesia". Jurnal Ekonomi \& Pendidikan 5:2(2008):171-192.

Wright, J. H. (2006). The Yield Curve and Predicting Recessions. Finance and Economics

Discussion Series, Federal Reserve Board, Washington, D.C., 2006-07.

Yudanto, Noor \& Santoso M. Setyawan. (1998). Dampak Krisis Moneter Terhadap Sektor Riil. Jakarta : Bank Indonesia. 